\title{
PENENTUAN PENYAKIT PARU DENGAN MENGGUNAKAN JARINGAN SARAF TIRUAN
}

\author{
Latifah Listyalina \\ Fakultas Sains \& Teknologi, Prodi Teknik Elektro \\ Universitas Respati Yogyakarta \\ Email: listyalina@respati.ac.id \\ Evrita Lusiana Utari \\ Fakultas Sains \& Teknologi, Prodi Teknik Elektro \\ Universitas Respati Yogyakarta \\ Desty Ervira Puspaningtyas \\ Fakultas Ilmu Kesehatan, Prodi Gizi \\ Universitas Respati Yogyakarta
}

\begin{abstract}
ABSTRAK
Organisasi Kesehatan Dunia (WHO) dan Organisasi Penanggulangan Kanker Dunia (UICC) memprediksikan terjadinya peningkatan kejadian kanker sebesar 300\% pada tahun 2030. Salah satu jenis kanker ialah kanker paru. Deteksi kanker paru dapat dilakukan menggunakan rontgen. Diagnosis kanker paru dapat dilakukan melalui pengamatan hasil dari citra foto rontgen secara teliti. Otomasi dari hasil citra $\mathrm{X}$-Ray dapat digunakan oleh praktisi kesehatan dalam pendeteksian kanker paru. Perancangan perangkat lunak jaringan saraf tiruan dari citra foto rontgen dilakukan melalui beberapa langkah yaitu pengolahan citra, seperti median filter, ekualisasi histogram adaptif, dan transformasi kosinus diskrit sebagai ekstraksi fitur citra yang selanjutnya dijadikan masukan jaringan saraf tiruan serta dengan didahului oleh proses pra pengolahan citra. Tingkat akurasi pendeteksian kanker paru melalui citra foto rontgen paru sebesar 72,97\%.

Kata kunci: citra digital; breadth search; depth search; generate and test; kernel; filter median; salt and pepper.

\section{ABSTRACT}

World Cancer Prevention Organization (UICC) and World Health Organization (WHO) said, it is predicted that the incidence of cancer in the world increased by 300 percent in 2030. One type of cancer is lung cancer. One detection of lung cancer is done by X-Ray. The health practitioner carefully observes the $X$-Ray images and diagnoses that are truly accurate in the lung cancer diagnosis in patients. To help the work of health practitioners in the detection of lung cancer, automation can be done from X-Ray images. The design of artificial neural network software from X-Ray images is carried out with several steps, namely image processing, such as the median filter, adaptive histogram equalization, and discrete cosine transformation as image feature extraction which is then used as input of artificial neural networks and preceded by pre-image processing. Obtained an accuracy rate of $72.97 \%$ in detecting lung cancer from images of lung X-Rays.
\end{abstract}

Keywords: breadth search; digital image; depth search; generate and test; kernel; median filter; salt and pepper.

\section{PENDAHULUAN}

Organisasi Kesehatan Dunia (WHO) dan Organisasi Penanggulangan Kanker Dunia (UICC) memprediksikan adanya peningkatan kejadian kanker sebesar $300 \%$ pada tahun 2030 , khususnya di negara berkembang, salah satunya adalah Indonesia. Salah satu jenis kanker ialah kanker paru. Kejadian kanker paru ditandai dengan adanya pertumbuhan sel yang tidak normal pada paru-paru sehingga paru-para mengalami perubahan struktur. Deteksi kanker paru dapat dilakukan menggunakan rontgen [1].

Identifikasi gambaran kondisi paru merupakan hal penting dalam penegakan diagnosis kanker paru. Diagnosis kanker paru dapat dilakukan melalui pengamatan hasil dari citra foto rontgen secara teliti. Otomasi dari hasil citra X-Ray dapat digunakan oleh praktisi kesehatan dalam pendeteksian kanker paru. Salah satu otomatisasi tersebut yaitu dengan memanfaatkan jaringan saraf tiruan. Otomatisasi ini 
diharapkan dapat menjadi suatu alat pembanding dari pendeteksian kanker paru hasil dari praktisi kesehatan dengan hasil dari otomatosasi ini.

Perancangan perangkat lunak jaringan saraf tiruan Perceptron digunakan sebagai alat bantu dalam mengklasifikasikan kanker. Klasifikasi dalam proses identifikasi tersebut meliputi paru normal, paru efusi, dan kanker paru. Sebelum proses identifikasi akan dilakukan pengolahan citra. Identifikasi dapat dilakukan dengan menggunakan Jaringan Saraf Tiruan.

Studi yang dilakukan oleh Saksono dkk. juga telah melakukan penelitian mengenai pendeteksian kanker paru tetapi digunakan Linear Discriminant Analysis sebagai metodenya dengan tingkat akurasi yang mecapai lebih dari 90\%. Kelemahan penelitian ini adalah identifikasi dilakukan hanya dengan data yang lebih sedikit sehingga akurasi belum maksimal [2].

Pendeteksian kanker paru dengan citra X-Ray juga telah dilakukan Deviasari dengan menggunakan Backpropogation dengan tingkat akurasi hasil penelitian 86,67\%. Backpropogation merupakan salah satu metode jaringan saraf tiruan yang bertujuan untuk klasifikasi dpengenalan pola yang membutuhkan waktu relatif lebih lama jika dibandingkan dengan metode lainnya. [3]. Peningkatan kualitas citra foto rontgen telah dilakukan oleh Listyalina berbasis tapis median dan ekualisasi histogram adaptif. Hal tersebut dibutuhkan untuk dilakukan sebab citra hasil rontgen thoraks memiliki kualitas citra yang rendah sehingga diperlukan adanya peningkatan kualitas citra. Citra dengan kualitas yang baik diharapkan dapat digunakan sebagai media deteksi kanker paru. Terdapat dua macam penilaian performa dari hasil penelitian ini, yaitu penilaian kualitatif di mana dilakukan dengan cara membandingkan secara visual citra masukan dan citra hasil pemrosesan serta penilaian kuantitatif di mana dilakukan dengan cara membandingkan nilai kontras citra masukan dan citra hasil pemrosesan. Namun pendeteksian penyakit paru belum dilakukan [4]. Studi yang dilakukan oleh Dharmawan dan tim melakukan pendeteksian kanker paru berdasar ekstraksi dan seleksi fitur yang kemudian akan dikelompokkan dengan membandingkan dua metode. Namun penelitian ini tidak melalui tahapan pengolahan citra [5].

Beberapa kekurangan penelitian-penelitian dipaparkan. Untuk itu, diperlukan teknik untuk menyempurnakan beberapa metode di atas dalam menentukan penyakit yang ada pada paru. Penelitian ini diharapkan dapat menentukan penyakit paru secara otomatis.

\section{TINJAUAN PUSTAKA}

\subsection{Kanker Paru}

Kanker paru adalah salah satu kondisi abnormal yang ditemukan pada paru ditandai dengan adanya pertumbuhan sel secara abnormal atau yang dikenal dengan tumor berbahaya. Kondisi pertumbuhan sel secara abnormal dapat berasal dari sel-sel yang terdapat dalam paru-paru. Namun, pertumbuhan sel secara abnormal ini dapat berasal dari sel (kanker) di bagian tubuh lainnya yang menyebar ke paru-paru. Kanker paru dapat terjadi, baik pada laki-laki maupun pada perempuan. Lebih dari $90 \%$ kejadian kanker paru berawal dari bronkus, yaitu suatu saluran udara terbesar yang masuk ke paru-paru. Kanker ini disebut juga dengan karsinoma bronkogenik [6]. Berikut merupakan gambaran kanker paru yang dijelaskan pada Gambar 1.

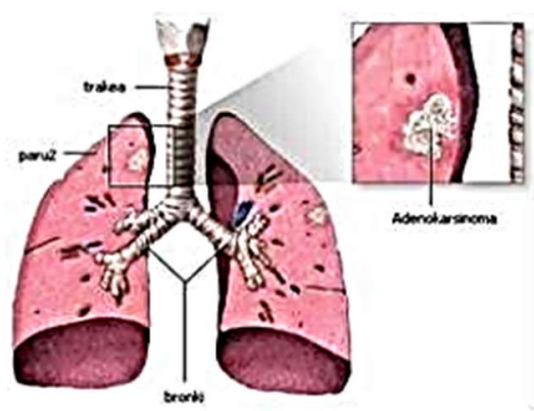

Gambar 1. Kanker Paru [7]

\subsection{Foto Rontgen}

Diagnosis kanker paru dapat dilakukan dengan beberapa tes seperti X-Ray dada, CT Scan dan Positron Emmision Tomography (PET) sejak adanya tanda dan gejala yang dirasakan pasien. Metode utama yang dapat digunakan untuk mendeteksi kanker paru adalah X-Ray dada. Metode ini digunakan untuk menggambarkan ukuran tumor, ketidakstabilan pembesaran nodus limfa, dan beberapa deteksi yang berhubungan dengan penemuan tumor pada paru-paru, seperti efusi pleura, lobar collapse, dan metastasis tulang [8]. 
Akuisisi X-Ray dada dilakukan menggunakan pesawat Rontgen atau pesawat sinar-x. hasil dari alat tersebut digunakan untuk melakukan diagnosis medis dengan menggunakan sinar-x. Sinar-x dihasilkan dan dipancarkan dari tabung roentgen yang diarahkan pada bagian objek yang akan diperiksa. Sinar-x melewati objek yang diperiksa sehingga akan menghasilkan berkas sinar-x yang kemudian akan diterima oleh reseptor gambar. Hasil tersebut akan diolah pula pada Analog to Digital Converter (ADC) yang selanjutnya akan ditampilkan pada layer monitor [9]. Skema sistem radiografi digital yang seusai dengan penjelasan tersebut digambarkan pada Gambar 2.

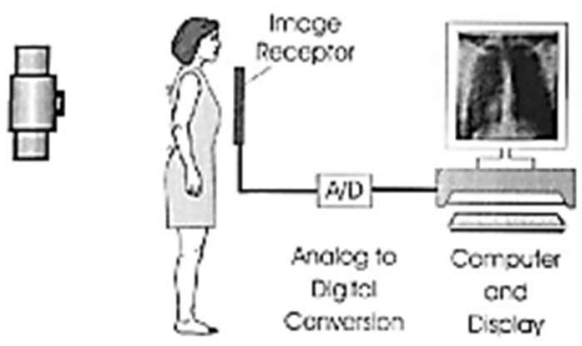

Gambar 2. Skema Diagram dari Sistem Radiografi Digital [10]

\subsection{Pengolahan Citra}

Citra merupakan sinyal dua dimensi yang memiliki fungsi, $f(x, y)$, dimana $x$ dan y merupakan koordinat spasial dan $\mathrm{f}$ di setiap pasangan koordinat $(\mathrm{x}, \mathrm{y})$ disebut intensitas atau tingkat keabuan dari suatu citra di titik $(\mathrm{x}, \mathrm{y})$ tersebut [11]. Ukuran atau dimensi citra mempunyai satuan yang beragam, misalnya titik, piksel, $\mathrm{mm}$ dan inch. Apapun satuan yang digunakan, semua citra dapat dapat dinyatakan dengan vektor 1 $\times \mathrm{M}$, citra digital juga dinyatakan dengan matriks berukuran $\mathrm{N} \times \mathrm{M}$ sebagai berikut [12].

$$
f(x, y)=\left[\begin{array}{cccc}
f(0,0) & f(0,1) & \cdots & f(0, M-1) \\
f(1,0) & f(1,1) & \cdots & f(1, M-1) \\
\vdots & \vdots & \ddots & \vdots \\
f(N-1,0) & f(N-1,1) & \cdots & f(N-1, M-1)
\end{array}\right]
$$

di mana $\mathrm{N}$ menyatakan baris atau tinggi, sedangkan $\mathrm{M}$ menyatakan kolom atau lebar.

Dari penjelasan citra di atas, untuk pengolahan citra sendiri merupakan pemrosesan sinyal dua dimensi. Pemrosesan tersebut dapat dikatakan pula dengan teknik yang bertujuan untuk memanipulasi dan memodifikasi citra dengan harapan dan sasaran tertentu. Aplikasi pengolahan citra dapat digunakan dalam berbagai bidang, seperti pendeteksian penyakit berbasis citra medis, pengenalan pola, penginderaan jarakjauh melalui satelit atau pesawat udara, dan machine vision [11].

\subsection{Jaringan Saraf Tiruan}

Jaringan saraf tiruan merupakan salah satu metode untuk mengklasifikasikan data yang konsep kerjannya meniru cara pembelajaran pada manusia. Metode ini ditemukan pertama kali oleh seorang neurophysiologist bernama Waren McCulloch dan logician bernama Walter Pits, namun penemuan saat itu masih sangat sederhana sehingga semakin maju teknologi, metode ini juga berkembang secara pesat. Dinamakan jaringan saraf tiruan sebab konsep kerjanya meniru cara kerja dari sel-sel saraf yang ada pada manusia di mana terdapat neuron, dendrit, dan inti sel layaknya sistem saraf pada manusia. [13]. Gambar 3 menggambarkan model jaringan saraf tiruan yang meniru sistem saraf manusia.

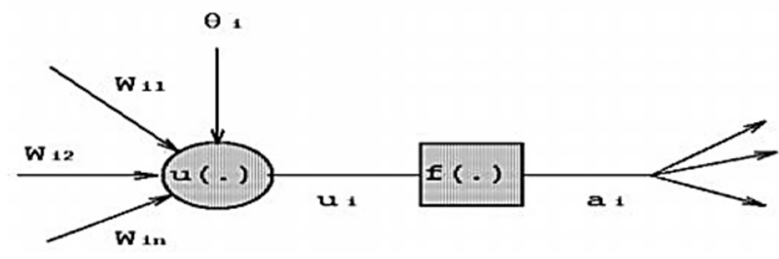

Gambar 3. Model Jaringan Saraf Tiruan [13] 


\section{ALUR PENELITIAN}

Gambar 4 menjelaskan mengenai alur (tahapan) dalam penelitian.

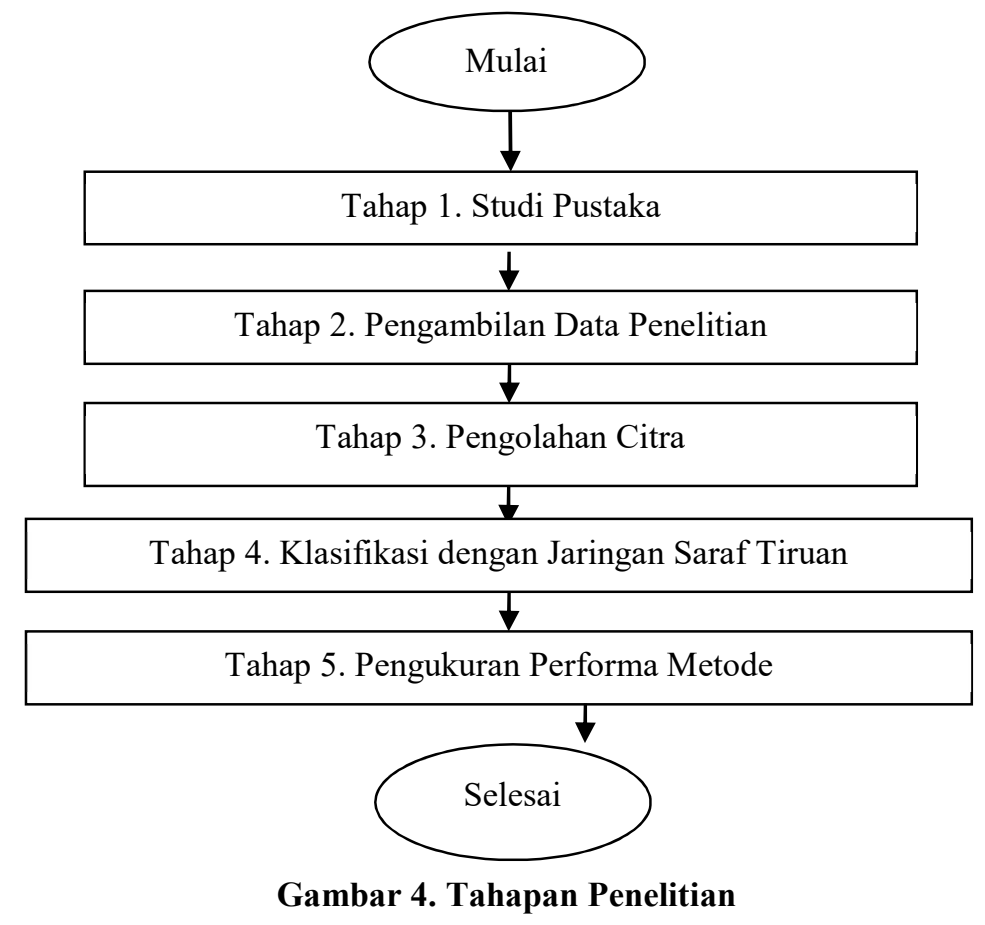

\subsection{Tahap 1. Studi Pustaka}

Studi pustaka merupakan langkah awal dalam penelitian yang dilakukan melalui pengkajian informasi dari buku dan studi terdahulu yang ditujukan untuk meningkatkan penelitian sebelumnya.

\subsection{Tahap 2. Pengambilan Data Penelitian}

Bahan yang digunakan dalam penelitian ini berupa data hasil foto rontgen toraks paru dari mesin XRay digital. Data tersebut diperoleh dari Rumah Sakit Dharmais, Jakarta.

\subsection{Tahap 3. Pengolahan Citra}

Pengolahan citra dimulai dengan menjadikan citra digital sebagai masukan, dilanjutkan dengan tahap praproses dan ekstraksi citra. Tahap praproses dilakukan dengan metode penyamaan fokus dan ukuran citra, penapisan citra, serta ekualisasi histogram, sedangkan ekstraksi fitur menggunakan koefisien dari transformasi citra.

\subsection{Tahap 4. Klasifikasi dengan Jaringan Saraf Tiruan}

Dari langkah sebelumnya, telah diperoleh fitur-fitur, yaitu koefisien transformasi citra. Fitur tersebut akan menjadi masukan pada tahapan ini sehingga akan diperoleh keluaran kelas-kelas kondisi paru setelah melalui pembelajaran pada jaringan saraf tiruan.

\subsection{Tahap 5. Pengukuran Performa Metode}

Analisis hasil penelitian dilakukan dengan membandingkan kecocokan hasil dengan acuan (dokter). Hal ini bertujuan untuk mendapatkan hasil penelitian yang dapat dipertanggungjawabkan. 


\section{PEMBAHASAN}

Tahap pengolahan citra dimulai dari didapatkannya data digital dari hasil foto rontgen toraks paru dengan format citra bitmap (*.bmp).

\subsection{Pra-Pengolahan Citra}

Pada preprocessing ini, dilakukan dua tahap, yaitu pemotongan dan penyamaan ukuran citra. Tahap ini dilakukan dengan tujuan memperoleh bagian citra sesuai kebutuhan penelitian ini. Proses pemotongan dan penyamaan ukuran citra dilakukan secara manual. Citra awal dari data rontgen toraks berukuran $2010 \times 2010$ pixel. Setelah dilakukan proses ini, citra menjadi berukuran 1760x1760 pixel. Pada penelitian ini, dilakukan perubahan ukuran/dimensi citra menjadi lebih kecil dari citra awal, yaitu citra awal berdimensi besar, yaitu1760x1760 pixel menjadi berdimensi lebih kecil, yaitu 320x320 pixel. Gambar 5 menunjukkan hasil pra-pengolahan citra.

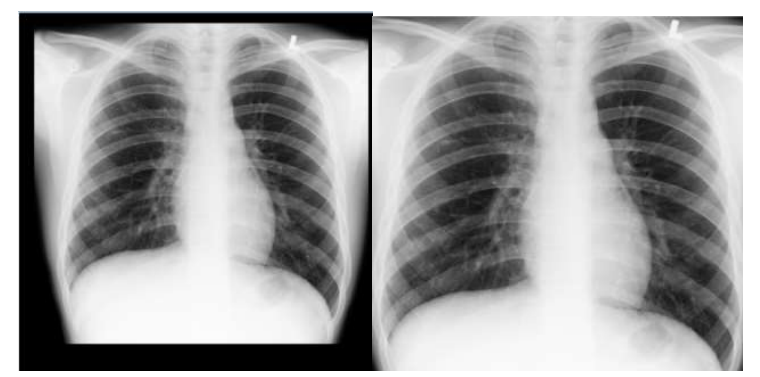

Gambar 5. Citra Sebelum (kiri) dan Sesudah (kanan) dilakukan Pra-Pengolahan Citra

\subsection{Median Filter}

Median filter merupakan salah satu metode yang bertujuan untuk menghilangkan derau yang ada pada citra. Pada citra thoraks yang digunakan pada penelitian ini, terdapat derau berupa bintik-bintik putih di sekitar paru. hasil dari aplikasi metode ini dihasilkan menjadi lebih jela dengan derau-derau tersebut menjadi berkurang bahkan hilang. Berikut merupakan contoh salah satu hasil citra sebelum dan setelah dilakukan aplikasi median filter pada Gambar 6.

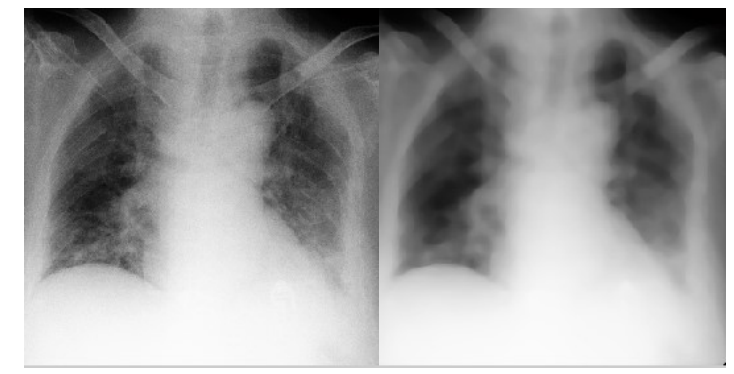

Gambar 6. Citra Sebelum (kiri) dan Sesudah (kanan) dilakukan Aplikasi Median Filter

\subsection{Peningkatan Kontras}

Citra hasil tahapan median filter menjadi masukan pada tahapan Adaptive Histogram Equalization. Metode ini merupakan salah satu metode dalam meningkatkan kontras pada suatu citra tanpa merusak kualitas citra secara keseluruhan. Hasil dari metode ini, diperoleh citra dengan detail dari citra tiap kelompok kelas semakin terlihat berbeda, yaitu kelompok kelas kondisi paru. Contoh salah satu hasil citra sebelum dan setelah dilakukan tahap Adaptive Histogram Equalization ini yaitu pada Gambar 7 berikut. 


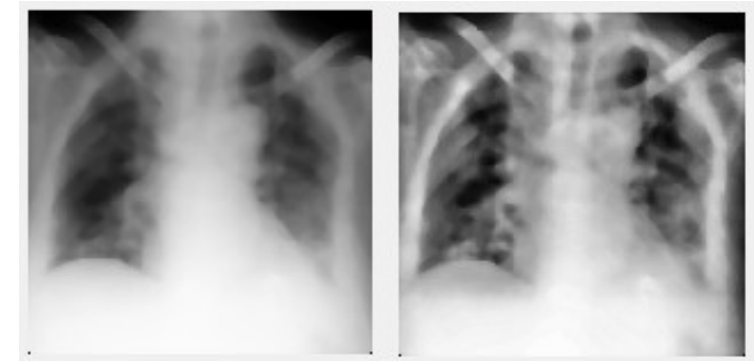

Gambar 7. Citra Sebelum (kiri) dan Sesudah (kanan) dilakukan Peningkatan Kontras

\subsection{Ekstraksi Fitur}

Fitur merupakan ciri khas yang terdapat pada suatu citra. Hal tersebut dapat dijadikan informasi penting yang nantinya menjadi masukan proses pembelajaran pada jaringan saraf tiruan. Adapun fitur pada penelitian ini ialah citra hasil dari Ekualisasi Histogram Adaptif. Citra tersebut dilakukan pemecahan menjadi empat area. Setiap matriks area dilakukan penjumlahan elemen. Selanjutnya, citra tersebut dihitung nilai koefisien Transformasi Kosinus Diskrit setiap pixel citranya, yaitu tiap nilai matriks citranya.

Melalui matriks pemecahan area tersebut, dihasilkan ukuran matriks yang lebih kecil dari ukuran matriks semula. Hasil penjumlahan elemen-elemen matriks area baru tersebut dapat dilihat pada Gambar 8 berikut.

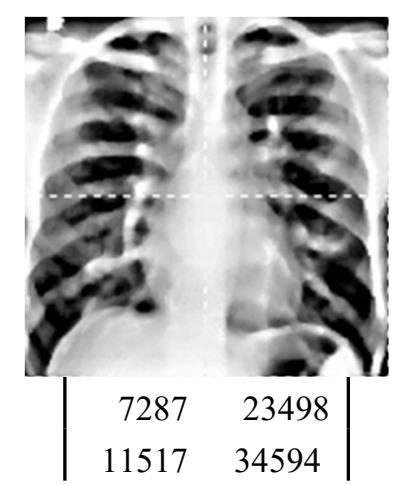

Gambar 8. Ilustrasi Pemecahan Area Citra Beserta Matriksnya

Dari gambar di atas, citra awal yang berukuran 320x320 pixel dipecah menjadi empat buah matriks region baru. Masing-masing matriks region berukuran 160x160 pixel.Hasil penjumlahan elemen-elemen matriks region berupa matriks berukuran $2 \times 2$ telah dipaparkan di atas. Selanjutnya matriks region tersebut diubah menjadi berukuran 1 $x 4$ untuk digunakan sebagai masukan Jaringan Saraf Tiruan.

\subsection{Jaringan Saraf Tiruan}

Jaringan Saraf Tiruan digunakan dengan tujuan pengklasifikasian data, yaitu data kondisi paru yang diperoleh dari pengolahan citra sebelumnya, yaitu fitur citra berupa koefisien Transformasi Kosinus Diskrit. Pada tahap ini, didapatkan eksekusi hasil pengelompokan kelas citra seperti citra kanker paru dan citra paru normal. Jaringan saraf tiruan terbagi menjadi dua tahap, meliputi tahap pelatihan data dan tahap pengujian data.

Dari proses pelatihan, didapatkan bobot akhir yang nantinya akan digunakan sebagai bobot pada proses pengujian. Bobot awal pada proses pelatihan nilainya berbeda dengan bobot akhir dari pelatihan. Hal tersebut berarti bahwa sistem telah "belajar" dan mampu menyesuaikan nilai bobotnya sesuai dengan nilai fitur masukan. Adapun bobot akhir, laju pelatihan, dan variasi laju pelatihan disimpan serta menjadi parameter yang akan digunakan saat pengujian.

Pada pengujian ini, ditampilkan semua data uji yang digunakan. Hasil dari proses pengujian dapat dilihat pada Tabel 1 dengan kelas (K) 1 ialah kanker paru, dan kelas 2 ialah paru normal; dan hasil diagnosis dokter ditandai dengan " $\mathrm{T}$ ". 
Tabel 1. Data pengujian

\begin{tabular}{cccccc}
\hline DATA & $\boldsymbol{D} \boldsymbol{1}$ & $\boldsymbol{D} 2$ & HASIL & $\boldsymbol{T}$ & $\boldsymbol{K} \boldsymbol{E} \boldsymbol{T}$ \\
\hline 1 & 25253 & 12857 & Kanker & 1 & Cocok \\
2 & 20746 & 5219.2 & Normal & 2 & Cocok \\
3 & 21757 & 13326 & Normal & 2 & Cocok \\
4 & 18526 & 6133.4 & Normal & 2 & Cocok \\
5 & 22494 & 8380.6 & Normal & 2 & Cocok \\
6 & 21226 & 5359.1 & Normal & 2 & Cocok \\
7 & 30922 & 16799 & Normal & 1 & Tidak \\
8 & 19788 & 7948.6 & Normal & 1 & Tidak \\
9 & 23743 & 11290 & Kanker & 2 & Tidak \\
10 & 19793 & 4373.7 & Normal & 1 & Tidak \\
11 & 26416 & 9120.5 & Normal & 1 & Tidak \\
12 & 22317 & 7360.9 & Normal & 1 & Tidak \\
13 & 30632 & 16917 & Kanker & 1 & Cocok \\
14 & 25791 & 14300 & Kanker & 1 & Cocok \\
15 & 30787 & 19981 & Kanker & 1 & Cocok \\
16 & 27610 & 17320 & Kanker & 1 & Cocok \\
17 & 33433 & 18056 & Kanker & 1 & Cocok \\
18 & 23020 & 9904.6 & Normal & 1 & Tidak \\
19 & 32056 & 18758 & Kanker & 1 & Cocok \\
20 & 23602 & 6507.5 & Normal & 1 & Tidak \\
21 & 25853 & 13896 & Kanker & 2 & Tidak \\
22 & 19681 & 1636.4 & Normal & 2 & Cocok \\
23 & 31911 & 18780 & Normal & 2 & Cocok \\
24 & 19954 & 3372.7 & Normal & 2 & Cocok \\
25 & 19411 & 7883.8 & Normal & 2 & Cocok \\
26 & 17532 & 2941.8 & Normal & 2 & Cocok \\
27 & 20474 & 3395.7 & Normal & 2 & Cocok \\
28 & 22871 & 9301.4 & Normal & 2 & Cocok \\
29 & 17382 & 3809.7 & Normal & 2 & Cocok \\
30 & 21280 & 8665.7 & Normal & 2 & Cocok \\
31 & 19448 & 7559.6 & Normal & 2 & Cocok \\
32 & 28608 & 16229 & Normal & 2 & Cocok \\
33 & 19495 & 5145.2 & Normal & 2 & Cocok \\
34 & 20028 & 5636.4 & Normal & 2 & Cocok \\
35 & 18395 & 6745.2 & Normal & 2 & Cocok \\
36 & 29046 & 17402 & Kanker & 2 & Tidak \\
37 & 17401 & 9452.5 & Normal & 2 & Cocok \\
\hline & & & & & \\
\hline
\end{tabular}

\section{KESIMPULAN}

Perancangan perangkat lunak jaringan saraf tiruan dari citra foto rontgen dilakukan dengan beberapa langkah yaitu pengolahan citra, seperti median filter, ekualisasi histogram adaptif, dan transformasi kosinus diskrit sebagai ekstraksi fitur citra yang selanjutnya dijadikan masukan jaringan saraf tiruan serta dengan didahului dengan proses pra pengolahan citra. Diperoleh tingkat akurasi sebesar 72,97\% dalam mendeteksi kanker paru dari citra foto rontgen paru.

\section{DAFTAR PUSTAKA}

[1] Kementrian Kesehatan RI. Kanker [Internet]. InfoDATIN, Pus. Data dan Inf. Kementeri. Kesehat. RI, Situasi Penyakit Kanker. Jakarta: Kementerian Kesehatan RI, Pusat Data dan Informasi; 2015. Available from: https://www.kemkes.go.id/resources/download/pusdatin/infodatin/infodatinkanker.pdf

[2] Saksono HT, Rizal A, Usman K. Pendeteksian Kanker Paru - Paru Dengan Menggunakan Transformasi Wavelet Dan Metode Linear Discriminant Analysis. Teknol Elektro. 2010;9:18-26.

[3] Wulan TD. Deteksi Kanker Paru-Paru Dari Citra Foto Rontgen Menggunakan Jaringan Saraf Tiruan 
Backpropagation. Surabaya; 2012 Aug.

[4] Listyalina L. Peningkatan Kualitas Citra Foto Rontgen Sebagai Media Deteksi Kanker Paru. J Teknol Inf [Internet]. 2017 [cited 2020 Mar 27];XII:110-8. Available from: http://jti.respati.ac.id/index.php/jurnaljti/article/viewFile/1/1

[5] Dharmawan DA, Listyalina L. Performance Analysis of Lung Cancer Diagnosis Algorithms on XRay Images. J Electr Technol UMY [Internet]. 2018;2:34-40. Available from: https://journal.umy.ac.id/index.php/jet/article/view/7429/4730

[6] Diananda R. Mengenal seluk-beluk kanker [Internet]. Shaleh AQ, editor. Jogjakarta: Katahati; 2009 [cited 2020 Mar 27]. Available from: http://inlislite.dispusip.jakarta.go.id/dispusip/opac/detailopac?id=25699

[7] PT Nucleus Precise. Newsletter 74 Kanker Paru-edisi 21 - DocShare.tips [Internet]. 2011 [cited 2020 Mar 27]. Available from: http://docshare.tips/newsletter-74-kanker-paru-edisi21_5745dd51b6d87fb3158b4570.html

[8] N.S.S. C. Hubungan Merokok dengan Kanker Paru di RSUP Haji Adam Malik Tahun 2009 [Internet]. 2011 [cited 2020 Mar 27]. Available from: http://repository.usu.ac.id/handle/123456789/21470

[9] Suyatno F, Istofa I, Yuniarsari L. Rekayasa Sistem Pengatur Parameter Pesawat Sinar-X Diagnostik Berbasis Mikrokontroller Keluarga MCS 51. Semin Nas III, SDM Teknol Nukl. Yogyakarta: Sekolah Tinggi Teknologi Nuklir-BATAN; 2007. p. 337-44.

[10] Yaffe M, Rowlands J. X-ray detectors for digital radiography - IOPscience. Phys Med Biol [Internet]. [cited 2020 Mar 27];42. Available from: https://iopscience.iop.org/article/10.1088/0031$9155 / 42 / 1 / 001 / \mathrm{pdf}$

[11] Suhendra A. Catatan Kuliah Pengantar Pengolahan Citra [Internet]. [cited 2020 Mar 27]. Available from: http://openstorage.gunadarma.ac.id/handouts/S1_TEKNIKINFORMATIKA/PengolahanCitra.pdf

[12] Jong JS. Jaringan syaraf tiruan dan pemrogramannya menggunakan matlab [Internet]. Yogyakarta: Andi; 2005 [cited 2020 Mar 27]. Available from: https://opac.perpusnas.go.id/DetailOpac.aspx?id=399808

[13] Yani E. Pengantar Jaringan Saraf Tiruan. Artikel Kuliah. [Internet]. 2005 [cited 2019 Jan 24]. Available from: http://tirezqiariantoro.files.wordpress.com/2007/05/jaringan_saraf_tiruan.pdf 